The Pilgrim's Progress Across Time: Medievalism and Modernity on the Road to Santiago

\title{
Paul Genoni
}

School of Media, Culture and Creative Arts Curtin University of Technology

\author{
GPO Box U1987 \\ Perth 6845 \\ Western Australia \\ p.genoni@curtin.edu.au
}




\section{The Pilgrim's Progress across Time: Medievalism and Modernity on the Road to Santiago}

This paper offers a reading of recent accounts of journeys on one of the great Christian pilgrimage routes, to Santiago de Compostela in north-west Spain. It focuses on the common narrative strategy of a disrupted sense of time expressed by the pilgrim-authors, and argues that this trope is intrinsic to texts that suggest that time has been 'crossed' and that the author has undertaken a 'medieval' experience. It is argued that this trope of crossing time is closely linked to two central themes of contemporary Santiago texts; the construction of the author as an authentic pilgrim, and the experience of forms of community that are outside the norm in the pilgrim's everyday life. These common themes in Santiago pilgrim narratives are said to be reflective the authors' distrust of modernity.

Keywords Pilgrims, Pilgrimage, Time, Santiago de Compostela, Camino, Way of St James, Authenticity, Community, Medievalism, Modernity

I felt the vibration of time in its grid of quadrants, where all roads are joined and mixed, becoming identical despite their being so different from each other.

(Paulo Coelho, The Pilgrimage ${ }^{1}$ )

It is a commonplace observation that travel induces a heightened engagement with time and space. The experience of moving through novel environments, often using unfamiliar modes of transport and being exposed to unaccustomed daily routines, reveals to a traveller the extent to which time and space are culturally mediated and locally enacted.

The purpose of this paper is to consider 'time' as it is experienced and narrated by a particular category of travellers who have an intense encounter with a displaced or disrupted sense of time. The travellers are pilgrims, and the discussion will focus on the pilgrimage to Santiago de Compostela in north-west Spain, arguably the most significant and popular of the remaining medieval Christian pilgrim routes in Europe. It will be argued that disrupted sense of time in Santiago narratives is a rhetorical device deployed to suggest a particular effect of travel that is, the capacity to induce in the traveller the sense that time has been transcended or 'crossed', and that the traveller has undergone an experience that is seemingly of another, earlier epoch.

This 'crossing of time' in pilgrim narratives will be read as an example of the negotiation of the relationship between past and present that is common in contemporary travel literature, whereby travel is narrated as a nostalgic encounter with a past made desirable by the crippling effects of modernity. As Heather Henderson has pointed out; 'The pervasive desire to reimagine the past leads to one of the central preoccupations with travel literature, the search for the lost innocence of a Golden Age'. ${ }^{2}$ It will be argued that the enduringly romantic and nostalgic attractions associated with historical places and experience reach a remarkably rich expression in Santiago pilgrim narratives, and that the accounts of 'pilgrim time' are both critical to the 
expression of a successful pilgrimage and deeply reflective of contemporary anxieties about many aspects of modernity.

\section{The Santiago pilgrimage}

To a significant degree the complex engagement with 'time' in Santiago pilgrim narratives is made possible by the long history of the pilgrimage and its associated literature. With a history that spans the duration of Christianity, and having been an active pilgrimage site for over 1100 years, the Santiago pilgrimage has developed an extensive array of rituals, symbols, and associated sites reaching throughout south-western Europe. Critically, these are kept alive as a 'living tradition' by the many thousands who continue to trek to Santiago each year. Santiago de Compostela, to a greater degree than other European pilgrimage sites, remains a place to which pilgrims travel by foot, horse or bicycle, rather than simply arrive by car, plane or train. By virtue of its long, unbroken history, anyone who walks to Santiago and identifies as a pilgrim, cannot help but be aware they are entering an association with the past by undertaking an activity that has remained remarkably unchanged for over a millennium.

The pilgrimage to Santiago was built around the interred remains of St James, one of Christ's disciples. St James was martyred in Rome in A.D. 44, and his body was said to have been transported to Spain for burial, where it was promptly forgotten by the small Christian community. Early in the $9^{\text {th }}$ century, however, St James was reputed to be appearing to Christian soldiers as they battled to regain large tracts of the Iberian Peninsula from the Moorish invaders. Soon after his remains were supposedly located in the place that now bears his name, Santiago being a contraction of the Spanish for St James. By the start of the $10^{\text {th }}$ century large numbers of pilgrims from across Europe were journeying to Santiago, to the point where it surpassed Rome and Jerusalem as the most popular Christian pilgrimage destination. It has been estimated that at its peak some half a million persons a year made the pilgrimage. ${ }^{3}$ In order to meet this demand there developed an extensive network of routes to Santiago from throughout Europe, and they form the basis of the paths that remain active in the twenty first century.

Although the pilgrimage began a slow decline in the thirteenth century, the knowledge of the pilgrim routes was never entirely lost and individuals continued to trek to Santiago. In the years since the Second World War the pilgrimage has undergone a major revival, referred to by anthropologist Janet Frey as the 'reanimation'. ${ }^{4}$ The extent of the reanimation can be measured by the number of credentials (Compostelas) issued each year by the Cathedral in Santiago to pilgrims who complete at least 100 kilometres on foot or 200 kilometres on bicycle. In 1987 only 2,905 Compostelas were issued, however by 2007 the number had risen to 114,026, with pilgrims from 122 nationalities being awarded their Compostela. In 2004, the most recent Holy Year - a year in which St James' feast day falls on a Sunday - 179,944 pilgrims received a Compostela. ${ }^{5}$

Crucial to the appeal of the pilgrimage in its reanimation phase is that Santiago is one of the few remaining Christian pilgrim sites to which many individuals travel by undertaking an arduous physical journey. For although the reanimation commenced in the post-war years with support from the Spanish (Franco) government, a rise in academic interest, and an extended period of social and political stability in western Europe, it really gathered pace in the 1980s as the pilgrim path was increasingly recognised as one of Europe's great 'walks' (Frey, 237-254). That this anachronistic mode of travel flourished in the face of modern alternatives creates a powerful link to the pilgrimage's medieval past, and for many contemporary pilgrims the 
experience of long-distance walking is the foundation on which their encounter with past time is built.

A number of the medieval pathways to Santiago remain active, with the most popular being the Camino Frances that runs westward from the French-Spanish border. The Camino Frances covers a distance of nearly 800 kilometres, and will usually be walked within a period of 30-35 days, with pilgrims provided with cheap dormitory-style accommodation in refugios. The concept of the 'Camino' is central to the modern Santiago pilgrimage. The word is Spanish for way or path, and indicates the physical road the pilgrims tread. It is also used, however, by pilgrims to refer to the experience of undertaking a pilgrimage; so they may refer to 'doing the Camino', or 'my Camino'. In this way 'Camino' expresses a concept that is dear to modern pilgrims - that the physical journey of the pilgrimage is a metaphorical equivalent of the spiritual journey through life. ${ }^{6}$

\section{The Literature of Santiago}

Pilgrim-authors who choose to write about the Santiago pilgrimage are engaging with a long established literary tradition. The earliest and most renowned text associated with the pilgrimage is the five volume life of St James, Liber Sancti Jacobi, commonly referred to as the Codex Calixtinus, which dates from approximately 1140. The fifth book of the Codex describes the pilgrimage in some detail, and has been referred to as the earliest European travel guide, ${ }^{7}$ including as it does many features of the various types of publications that are now broadly described as travel literature. It is in part a directional guide, with maps of the major routes; in part a cultural guide, with notes about the religious buildings, monuments and relics encountered; in part a traveller's guide, with information about lodgings and meals; and in part a travel memoir, in which the author French monk Aymery (or Aimery, or Aimeric) Picault (or Picaud), recounts incidents from his own pilgrimage. It even functions as a phrase book, by including handy words and phrases to use with the peoples encountered. ${ }^{8}$

The Codex was, however, only one of a number of medieval documents narrating the pilgrimage to Santiago, and this body of literature has expanded over the centuries to include numerous academic works from various disciplines including anthropology, sociology, history and theology. A bibliography published in 1991 of works dealing with the pilgrimage and the cult of St James runs to 2,941 entries, of which 2,493 were published in the twentieth century. ${ }^{9}$ This explosion of publishing has continued in recent years and has crossed from an academic to a general readership, with a rapid growth in the number of personal accounts of contemporary pilgrimage on the Camino. Perhaps no other single journey - as opposed to destination - has given rise to such an extensive bibliography of popular travel writing over the last quarter of a century. It is likely there have been approximately 120 personal accounts published in English alone in this period, ${ }^{10}$ although they are under-represented in the scholarly accounts of contemporary travel writing. For while medieval pilgrim narratives have been described as a 'forgotten genre', 11 this is also true of contemporary accounts, with Simon Coleman and John Elsner concluding that 'relatively little work has been explicitly devoted to the issue of pilgrimage as writing, and specifically as a form of travel writing'. ${ }^{12}$ The examination of 'tourists with typewriters ${ }^{13}$ has not included pilgrims with pens.

From the early days of the reanimation pilgrim-authors have expressed an appreciation of the long tradition of Santiago literature. Walter Starkie, writing in The Road to Santiago (1957), the first of the major post-reanimation accounts, makes constant reference to earlier Santiago 
texts, particularly to Aymery Picault who he refers to as 'our old twelfth-century mentor' ${ }^{14}$ Many, if not most, subsequent accounts also make reference to Picault and the Codex Calixtinus, and frequently to other pre-modern and modern accounts of the pilgrimage. ${ }^{15}$ Other writers associated with Santiago and often invoked in contemporary accounts include Walter Raleigh, Dante, and renowned nineteenth century traveller Richard Ford. In recent times popular Santiago narratives have included 'celebrity' accounts by Brazilian novelist Paulo Coelho, actress Shirley MacLaine, ${ }^{16}$ and German comedian Hape Kerkeling. ${ }^{17}$ The Camino has also attracted widelyread travel writers such as Ben Nimmo ${ }^{18}$ and Tim Moore. ${ }^{19}$

There are numerous reasons why modern pilgrims are drawn to the Camino. Although the Christian associations have traditionally been the major attractor - and remain so for many pilgrims - there have always been other reasons for undertaking the arduous journey. Diana Webb $^{20}$ has pointed out that the motivations for medieval pilgrims were far from uniform, and it is apparent from the testimony of both pilgrim-authors and scholars that the motives driving contemporary pilgrims can be equally complex. The pilgrimage might be undertaken wholly or in part for its religious elements, but other factors include personal spiritual development; the popular touristic; and the long-distance adventure walk. As anthropologist and Santiago pilgrim Nancy Frey has explained, the motivation for modern pilgrims are multiple, 'layered', and likely to evolve over the course of the pilgrimage (28-29; 44-46), and Nicholas Parsons describes the pilgrimage as 'a postmodern experience where (almost) any or no motivation for following the Way of St James (the Camino) is equally valid’ (71) .

It is apparent, however, that the motive for a pilgrimage will influence a subsequent narrative. As Alison Russell has noted, 'the way people travel and the way people experience the world are inextricably linked to how they render the journey and the world in literature'. ${ }^{21}$ For this reason one should be wary about over-generalising pilgrim narratives, but nonetheless it is possible to trace recurrent themes and tropes in Santiago texts. As will be examined, these commonly relate to the personal growth that is the result of turning one's back on modernity and undertaking what is imagined by the pilgrim-author to be a journey that is inherently medieval. As Elyn Aviva attests in declaring her reasons for walking to Santiago, this sense of having 'crossed time' might not only be an outcome of the journey, but a motivation.

Ours would be a multiplex pilgrimage, full of images and intents; a private quest, a shared adventure, a journey across a geographical space, a voyage back in time, walking in the footsteps of the millions of pilgrims who had gone before us. ${ }^{22}$

\section{Medievalism and modernity}

A notable characteristic of contemporary Santiago narratives is their frequently expressed nostalgic and romantic attachment to an earlier time, closely coupled with a distrust of modernity. As Nancy Frey has commented:

A striking aspect of the reanimation of the Camino is the appeal to nostalgia and 'feelings and things of the past'. There is a valorization of and nostalgia for nature and humankind's connection to it, the quaint and the technologically obsolete. (261)

Frey notes that modern pilgrims use the term 'medieval' quite imprecisely in order to broadly connect their experience with a past that is looked upon with nostalgic yearning (41). And what 
is true of pilgrims in general is also true of pilgrim-authors, for whom the term 'medieval' serves to invoke a range of desirable characteristics that are imaginatively associated with the Santiago pilgrimage in its imprecisely defined heyday. For the modern pilgrim-author the nostalgic associations of the medieval past frequently include elements of cliché - 'the age of chivalry and romance' (Kevin 210) - but also express a belief that within the medieval period, and particularly in the figure of the pilgrim, are found a range of desirable qualities and values that have been lost in modernity. These values are associated partly with the mechanics of pilgrimage - the arduous journey that requires the pilgrim to undergo a demanding physical test - but they are also connected with the medieval Catholic concept of penitence, which transformed into its modern secular counterpart of personal spiritual growth, is often narrated by the contemporary pilgrim as the essence of their experience. A pilgrimage is therefore undertaken not simply in order to reach Santiago (which for secular pilgrims does not even have the attraction of the association with St James) but in order to undergo the journey itself, with all the personal challenges that this entails. Kerry Egan is but one pilgrim-author to claim that the modern attraction to pilgrimage is the result of it being an essentially medieval process by which the long distance walker is transformed into something other - a true 'pilgrim'. ${ }^{23}$

The medieval pilgrimages were more focused on the process of the pilgrimage, on becoming and being a pilgrim, than on the visions or miracles at the pilgrimage site. Even today, the focus of the pilgrimage to Santiago is on the journey itself and on the transformation of becoming a pilgrim over the course of the journey. (28-9; see also Aviva 254)

The trope of medievalism was established by Starkie in The Road to Santiago, with his frequent references to the desirable qualities of medieval pilgrimage. In his opening sentence Starkie declares his interest in medievalism by announcing that the journey to Santiago is comprised of the 'backward journey through Time and the forward journey through Space' (1). As Starkie's narrative unfolds it is clear that his fascination with the Camino is based on the values he associates with medieval pilgrimage, and his belief that in 'following the road of St. James we are forever reminded by the churches, the shrines, the hermitages, of medieval man and his faith in God and the Church' (91).

At times, such as when he encounters an elderly pilgrim, Starkie evokes the conceit of the authentic pilgrim. The concept of 'authenticity' is - as will be discussed - frequently used by contemporary author-pilgrims to imaginatively link their experience to the medieval ideal. When Starkie first encounters the elderly pilgrim the man is 'absorbed in prayer', and by his piety, dress and demeanour is immediately identified as being authentically medieval and thereby at odds with modernity.

The old man was so much the embodiment of the mediaeval pilgrim with his habit, his broad hat, his long staff and bare feet that I felt ashamed of my modern clothes and my well-shod feet. (231)

Starkie falls in with the old man and walks with him for some distance, learning that he has lost his family in the war, and that he lives by a vow of poverty and walks the pilgrim paths ceaselessly as a form of expiation for his former life as a successful lawyer who 'lived thoughtlessly’ (232). 
Edwin Mullins in The Pilgrimage to Santiago (1974), the second influential book of the reanimation after Starkie's account, recalls a remarkably similar experience. Mullins also encounters an elderly pilgrim who again displays the physical characteristics of his authenticity.

His skin looked shrunken within his clothes, and his bones within his skin, and a scallop-shell dangled on a thong from his rucksack ... [S]omething of the mediaeval spirit of pilgrimage came alive in this tallowy figure. (119)

Mullins converses with the old pilgrim and finds that he too has lost his wife and surrendered a life of middle class respectability in order to dedicate himself to pilgrimage. In this case the criticism made of modernity is even more emphatic.

His son was working on Concorde in Toulouse . . . but that was not his pace at all. Lord no! His son ate too much and had a holiday flat in one of the new developments along the Languedoc coast; his grandchildren had long hair or else they took la pilule [the pill] and he didn't understand what was going on. The $20^{\text {th }}$ century was slipping away from him, and he had taken to the road back to make his peace and affirm his values. (119)

To both Starkie and Mullins modernity is implicated in a decline from the values associated with true, that is medieval, pilgrimage, and their spirits sag when they find it encroaching on the pilgrim experience. Starkie regrets that the Camino is 'overwhelmed on all sides by the modern materialistic world' (115), and bemoans 'the materialism which has sapped the spiritual strength of the people everywhere and weakened the moral law' (303). Mullins journey takes him to Ponferrada where he encounters 'the industrial smog that bathes this jerrybuilt heap of modern Spain and my heart sank into the kind of stupefied disbelief I associate with American television entertainments' (188).

Following the lead given by Starkie and Mullins, contemporary authors frequently narrate their Santiago pilgrimage as a quest for the mythic experience and values they associate with medieval pilgrimage, and in turn they reveal their deep scepticism towards modernity. The experience they describe as 'medieval' is based on a journey of personal growth shared with a community of fellow pilgrims, undertaken in transcendent natural and built environments of deep cultural and historical significance, and utilising modes of transport that have dominated the pilgrim trail for a millennium. As will be explored, however, the narrative expression of these key elements is determined by their own experience as men and women shaped by contemporary western cultures. For while they may self-consciously seek to (re)construct a medieval pilgrim experience, their narrative is inevitably more revealing of their own conflicted relationship with modernity than it is of medieval pilgrimage.

\section{Time in contemporary pilgrim narratives}

In order to foreground their engagement with medieval pilgrimage contemporary pilgrim-authors use a variety of rhetorical strategies to suggest that they have - in an imaginative sense transcended time in a way that provides them with something akin to a medieval experience. These rhetorical devices are necessary because, to a considerable degree, pilgrim narratives are shaped by the practicalities of the journey to a linear and repetitive account of time. That is, 
conventional pilgrim writing is almost universally presented in diary form, recalling a journey with a definite beginning and end, moving predictably and repetitively through time and space, with days often marked off by the beginning and end of a chapter or sequence in the text. However as pilgrim-author Jack Hitt realised, a strictly chronological account presents problems in narrating a pilgrim's lived experience.

No one wanted to hear the diary version of the walk - the day-to-day home movie tedium of where and when and what ... [P]ilgrimage stories can’t be told in real time, even though . . . we are hopelessly moored to it. I had to look harder at the moments and think like a writer. Where were the good bits that would be great stories for anyone, not just me? This is the difference between diaries and writing, between bad pilgrim accounts and good ones, between boring kiddies tales and bits of incandescence. $^{24}$

Tony Kevin is another who recognises the necessity of fracturing the routine chronology of sequential movement in order to narrate the pilgrim's experience of time and space.

So if I were to go on giving you a precise, day-by-day account . . . it would be true in one sense but less relevant in another, because my walk had now become a different sort of observed reality . . . Of course I still had to navigate; I still had to know roughly where I was, and take in the markers of a day's journey from A to B. I had to remain, to that limited extent, planted in physical reality. But to let my mind slide into a different rhythm of existence - that was a rare and lovely feeling. (171)

\section{Time as past}

The pilgrim-authors' disruption of a 'normal' experience of time in order to express this 'different rhythm of existence' is achieved in various ways. In its most straightforward form authors adopt a narrative strategy that is commonly deployed in contemporary travel writing by emphasising how their encounter with pre-modern environments transports them imaginatively to an earlier epoch. As pilgrims traverse ancient pathways, bypassing unrestored villages, decaying churches, and other physical reminders of the Camino's long history, they often express the belief that they are 'in' another time. By simply arriving at his starting point of Saint Jean-Pied-de-Port ('a lovely medieval town') Dave Pivonka immediately 'felt as if I had been beamed there by some time machine'. ${ }^{25}$ Kerry Egan is another of the many pilgrim-authors seduced into declaring that her experience is akin to travelling across time.

There are places along the Camino - where farmers till their fields with teams of oxen, or where ancient standing crosses carved with Romanesque images mark the way - where one could begin to believe she was not only walking across space, but across time as well. (16)

In many pilgrim narratives ancient buildings, sites and landscapes are eagerly embraced for their capacity to imaginatively transport the author into the past. And, as Bettina Selby's account indicates, they can find in these moments evidence that the past holds different values to the present. 
In spite of the cold and the general lack of comfort I felt there was a sense of rightness about the pilgrim lodgings ... . If threads of troubadour song had drifted from the rafters, together with the strains of a distant hurdy-gurdy it would not have seemed out of place. . . The whole place was redolent of the times and events that had shaped it. Vulnerable and threadbare now, it had faced twelve centuries of changing fortunes ... That it had survived all this and still offered shelter to pilgrims of today's materialistic world seemed little short of miraculous. ${ }^{26}$

Conrad Rudolph declares that in experiencing this intense engagement with history the pilgrim is exposed to a convergence of past and present that is 'one of the most fundamental elements of human existence, [but] one that's almost systematically ignored in modern life' (38). Rudolph concludes that on the Camino 'feelings so unconnected with modern existence become an everyday part of life' (23), and that this integration of past and present is an integral component of pilgrimage that differentiates it from other forms of contemporary travel.

It is the deep and sustained integration of this dynamic of past and present along the pilgrimage routes that accounts for why the pilgrimage is not a vacation or tour but a journey, not a succession or postcard-worthy sites but a progression of time and space in which both the implicit denial and the embracing of time and space inherent in the acceptance of history operate. (38)

For other pilgrim-authors this power of the pilgrimage to conjure up past time resides in the Camino itself. According to Almis Simankevicius the pilgrim's way possesses a 'special energy', which 'is like a time tunnel, allowing movement between past and present'. ${ }^{27}$ Simankevicius punctuates his text with a series of 'reveries' whereby he is imaginatively transposed to the Camino as it was at various times in its past (for example, 12, 56, 74, 91, 105), a strategy that is also adopted by Jane Christmas (218).

\section{Time as 'now'}

Another effect of 'time' that is frequently reported in pilgrim narratives is that the exigencies of the pilgrim life produce a heightened awareness of the present, this moment. Many pilgrimauthors narrate variations on a phenomenon that they frequently express as 'living in the now', which is again represented as a personally fulfilling outcome of the pilgrim experience. Joyce Rupp is typical:

The Camino forces the pilgrim into the present moment. There's really nowhere else to go ... If a pilgrim walks long enough, he or she gradually just walks, just travels, just lives, from one footstep to the next, entering every moment with greater and greater awareness. All of one's energies are drawn into the present situation ... the Camino draws one to live in the Now. ${ }^{28}$

Tony Kevin narrates a similar experience of being compelled to experience the pilgrimage in the very moment of living it: 
I was a little capsule of life crawling across a vast landscape, where only the here and now held any meaning for me. Time had expanded enormously: yesterday was already a fading memory, and tomorrow just a distant prospect. (170)

Likewise, Ben Nimmo relates how he had 'lost track of the days, the weeks, everything but the now, bright and compelling' (78), and Susan Alcorn that, 'This is definitely living in the moment. We're finding that our minds are free of anything but walking, food and shelter'. ${ }^{29}$

For Mary Wilkie, it is the desire to live more intensely in the present, the now, that is a motivation for her pilgrimage. It is a goal she associates with her wavering Christian faith with its focus on deferred, eternal reward.

If I had any spiritual goals for the journey it was to cultivate a greater sense of presence, a greater ability to live in the here and now. Perhaps the loss of a sense of belief was a necessary condition for becoming more aware of the present. (22)

If for Wilkie the capacity to live in the moment is associated with her diminishing Christian faith, for Elizabeth Best it is a part of sloughing off her 'normal' self - a disavowal of an identity shaped by the day-to-day acquisitiveness associated with modernity.

Out here material things don't mean as much as they did at home. Letting go of them is like cutting a second umbilical cord. Expecting nothing, accepting everything, surrendering to each moment as it arrives, having the courage and faith to trust you have everything you need to be okay. I have less in my pack now than I did when I came. Tomorrow I will have less than I have today. (89; see also 2)

What these various manifestations of the pilgrim's experience of time have in common is that they are underpinned by a contention, both explicit and implicit, that the pilgrim encounters time in a way that is more fulfilling than is normal in modern western, industrialised society, and in a manner that is personally healing. As anthropologist Nancy Frey recalls, her own pilgrimage corrected her relationship with time, from being a dysfunctional modern experience of deficit, to one based on an acceptance and proper use of the time at her disposal.

The Camino allowed me, at least briefly, to step off the treadmill and put my unhealthy relationship to time in perspective. How can I flow with, rather than against, time? (217)

Kathryn Harrison reaches a very similar conclusion.

Among the promises of Santiago is an altered relationship with time, the attempt to measure it step by step. Not to defeat time, nor to fight against its restlessness, but to perceive time, one of the faces of God - a face routinely obscured by our modern multitasking lives. (7)

\section{Time as 'slowed'}


Another means by which pilgrim-authors represent the manner in which their experience of time is shaped by their journey is to invoke the slowness of the pace, the extreme distances covered, and the vastness of the Camino, to emphasise how their perception of time is modified or 'slowed'. As Elyn Aviva noted, 'Time itself becomes different, marked not by the clock but by the movement of the body through space' (xii). This capacity of the pilgrimage to alter the perception of time becomes a keynote of Tony Kevin's account, as he describes 'the most wonderful quality of pilgrimage - how it slows down and separates time into discrete bundles' (11); and Conrad Rudolph emphasises that the slow pace is 'not a normal experience for a modern American' (35), and that it is an experience of time that belongs to another, earlier epoch. For Rudolph this slowing of time has a healing effect as the pilgrim surrenders their modern expectations of movement through space and adapts to the 'medieval speed' of the walk.

What there is is enormous solitude and silence. And the result of all this - not just for me but for all the other long term pilgrims I spoke with - was a sense of timelessness, or very slowly moving time; the sensation of a timelessness of progress, that time and distance, the seemingly basic components of all travel, no longer played a leading role in the journey. I completely lost sense of time and, to a certain extent, of space . . . In the course of this downshifting from modern to medieval speed, the pilgrimage acts like a mental sauna, sweating out the stress of daily life ... (35-6)

Arthur Paul Boers similarly recounts how 'the relaxed pace of walking transformed my sense of time'. ${ }^{30}$ Boers claims that walking is the 'speed of life' (162) and inherently opposed to the speed and values implicit in modernity.

Walking is an act of dissent; it is countercultural . . . a demurral against flagrant expenditure of non-renewable resources. In opposition to the noise of motor vehicles. Counter to the ugliness of cities and communities shaped to accommodate cars and discourage pedestrians. In opposition to all the burying of topsoil under asphalt. (164)

Many pilgrim-authors use the pretext of their slow speed and the necessity of spending long hours in solitude to reveal to themselves (and their readers) their essential selves. Elizabeth Best relates how using the uncommon experience of abundant time resulted in a transformation to a more fulfilled version of herself.

What I appreciate most about Camino life, however, is time. Time to think, to breathe, to talk, to ponder, to explore, to learn, to interact and grow, to enjoy food and wine and moments and views. Time to give thanks for what you have, identify what you don't have and work on things you need. Time. And as much of it as you like. I'm going to miss it and I know, in time, I will miss the person I am with it. ${ }^{31}$

This experience of plentiful time for solitude and reflection provides authors with a precursor to other means by which chronological time on the Camino can be ruptured. Granted the luxury of 'slowed time' they are taken out of the present, and constantly confronted by memories of their own past time that arrive unbidden. As Best notes, 'It's strange, the things you find when you are tortured by time'. 
There's the occasional random memory as well, flashbacks that spring from nowhere to surprise me: a girl I knew in high school but haven't seen since; a verse of a poem I wrote a few years ago; a childhood Christmas; the girlfriend I had coffee with three weeks earlier, my best friend's wedding; a car accident; someone I lost and loved. Eight hours is a long time to spend in thought, day after day. (58)

Kathryn Harrison also finds herself dealing with 'the unaccustomed days of solitude, body occupied, mind freed, and the linear, implicitly narrative aspect of a walk from here to there', and finds that 'on this road the past has returned'. ${ }^{32}$ As with Best it returns in the form of fragments of her childhood.

I remember conversations from my childhood, dialogues that unfolded between adults, frustrating in their opacity. Now, mysteriously, they are available to me, as if replayed to my adult and knowing ears. (102)

Tony Kevin experiences a similar response to his protracted time spent walking in solitude. As with Best and Harrison the 'benign endorphins of long-distance walking' induce intense recollections of past people and events that lead to an enhanced self-awareness.

There was unlimited time to muse; to try to remember old snatches of poetry or music learned at school; to reflect on old loves, friendships, estrangements, enmities—all the knots and tangles of a complicated personal history. . . It was a steadily developing process of mental relaxation and discovery of truth about myself. (168)

And Kevin Codd provides yet another account of the slippage in personal time that occurs when a pilgrim is alone with his thoughts on the Camino, as his long and solitary journey inevitably leads to meditation on his past life and former selves.

Odd and fairly random moments from my life appear; a scene comes back to mind with clarity and immanence and the feelings surrounding that moment, sometimes sad, other times pleasant, return to visit as well; a few are accompanied by shame but most with gratitude. One memory leads to another and so on and so on and the hours pass. $^{33}$

Best, Harrison, Kevin and Codd weave these memories of their past into narratives of personal transformation, whereby the memories and images of their former selves are integral to prolonged meditations on crises that have haunted their lives. For the secular Best, her pilgrimage induces a deep narrative reflection on childhood trauma and a subsequent battle with eating disorders; for Harrison it is a process of coming to an understanding of past family trauma; Kevin's Christian pilgrimage becomes a means of dealing with the aftermath of a traumatic workplace experience and regaining a 'healthy mind in a healthy body' (297); and priest Codd declares that 'I need that time and space ... to meet myself again ... [and] to get to know Jesus, pilgrim to pilgrim' (46). These four Santiago pilgrim-authors, in common with many others, have undertaken the pilgrimage in order to open themselves to the possibility of change in their lives. As noted there are numerous motivations for travelling on the Camino, but the one that most frequently leads to a textual outcome (that is, a form of travel writing) is that 
which is grounded in the desire for personal growth or transformation. One of the key narrative strategies for expressing this attempt to address a personal crisis is that which relies upon the author experiencing an imaginative - as well as physical - release from the time and space they usually occupy as natives of modern, western societies.

By virtue of these various rhetorical disruptions of 'normal' time pilgrim-authors find a means of forging a link to an altogether different time, that pre-modern moment - loosely described as 'medieval' - that they imagine provided a richer and more fulfilling engagement with life. Moreover, this transformed experience of time is presented as being integral to the pilgrimage and an important means of fulfilling the goal of personal transformation. In narrative terms, this disrupted experience of time frequently culminates in the author's claim to having escaped or transcended modernity and engaged with an experience they claim to be medieval. As Frey concluded:

In the medieval pilgrimage and pilgrim modern pilgrims find a direct link to the past, an authenticity based on sacrifice, endurance, and austerity imagined to have been lived by the medieval pilgrim, and a community of souls united by the rhythm of their feet as the second millennium comes to a close. (15)

The twin concepts of 'authenticity' and 'community' raised by Frey are critical to many contemporary pilgrim narratives, wherein they serve to sharpen the distinction between the medieval and the modern, and ground the author-pilgrims' claims to having undergone a transforming experience that is essentially of another time.

\section{Authenticity}

The issue of a how individuals relate to the concept of the authentic pilgrim is central to many contemporary Santiago narratives. At some point most pilgrim-authors address the issues raised by their presence on an ancient pilgrim path in the twentieth or twenty first century. These include; what exactly is a pilgrim, and am I one? How does identifying as a pilgrim shape my journey? To what extent do I adhere to the traditions of medieval pilgrimage? How do I relate to others on the Camino if they do not share my values as a pilgrim? Will I engage with experiences that belong to the world of the tourist, rather than the world of the pilgrim? For many pilgrimauthors the tension that drives their narrative is not that which separates the religious and secular pilgrims, but that which separates the authentic 'pilgrim' from the inauthentic 'tourist'.

Pilgrim-authors frequently invoke the concept of authenticity to describe various forms of pilgrimage in a quite uncritical manner, assuming that it constitutes an opposite to the superficial (or inauthentic) Camino experience they describe as 'tourism'. ${ }^{34}$ As Conrad Rudolph argues in the course of establishing his own authenticity:

A pilgrim is not a tourist. You have a deeper experience. The locals look at you as a special experience, as authentic. Despite the distance, you are a participator, an authenticator, even more than the locals themselves. . . This is why the pilgrimage is not a tour, not a vacation, not at all like a trip from point $A$ to point $B$, but a journey that is both an experience and a metaphor rather than an event. This is why the pilgrimage must be done on foot, never on bicycle; why you must stay in refugios, not in hotels; and why the experience should be long and hard. And this is why you 
then experience a place and culture in a way vastly different than a traditional visitor or even a local. (33-4)

This distinction between pilgrim and tourist is resolutely maintained by other pilgrimauthors, for whom it describes and justifies their own place on the Camino. In these narratives the authentic pilgrim (including the author) is carefully positioned as the privileged bearer of the spirit of medieval pilgrimage, while tourists are derided for the faux and pretentious nature of their experience - what Lee Hoinacki disparages as 'the emptiness and degradation of tourism' (35). Whereas recent scholarship has frequently emphasised the similarities between pilgrims and tourists, ${ }^{35}$ - Victor and Edith Turner concluded that 'a tourist is half a pilgrim, if a pilgrim is half a tourist ${ }^{36}$ - Nancy Frey identified how emphatically the distinction between the two categories of travellers is maintained on the Camino. Moreover, Frey also noted that not only is there a distinction between pilgrims and tourists, but also how a hierarchy emerges between different categories of pilgrims according to a perceived scale of authenticity. Issues of motive, mode of travel, distance covered, type of accommodation, going solo or in company, and the exact route to be followed, all being contested in the name of authenticity (Frey 125-36).

Many narratives attest to the existence and rigidity of this hierarchy by carefully distinguishing between different 'classes' according to the extent of their authenticity (Aviva 96, 259, 262; Boers 121, 182-85; Codd 138, 189, 227; Hitt 177, 181, 230; Hoinacki 69, 129, 145; Kevin 31; O’Regan 37; Tarver 107, 180). In essence, the pilgrim-author's claim to authenticity rests on the extent to which their pilgrimage imaginatively resembles that of their medieval forebears, and they often express contempt for others who adopt the comforts or conveniences of modernity for transport, accommodation or support. ${ }^{37}$ To the conscientious pilgrim the presence of these less-authentic pilgrims on the Camino disrupts the attempt to be authentic, as the nonauthentic acquire neither the spirit nor the demeanour necessary for genuine pilgrimage and thereby destroy the 'authentic' pilgrim's medieval fantasy. Lee Hoinacki, for example, is one of many pilgrim-authors to direct anger at cyclists (see also, Best 167; Kevin 7; O’Regan 67) whose use of modern apparatus for transport constitutes ‘a conspiracy of brutishness' (216) against authentic pilgrimage.

A number of bicyclists came in during the evening, making the small dormitory crowded. With their loud talking until far into the night, they also made the place distinctly hostile to sleep. These young men fell exactly into the pattern that I have come to see: they are always inconsiderate, uncivil, noisy. But I never notice these traits among those who are walking. Why this great difference? (145)

Kevin Codd recounts similar encounters with pilgrims, who although pedestrians, are condemned because they rely upon a coche de apoyo (transport vehicle).

The first hour of the morning, the most precious of any day, is made less so by a squawking family of pseudo-pilgrims who walk along at my pace so that I cannot escape their annoying company. They yak and yammer and laugh bawdily and generally disturb the peace without letting up. Only one or two of the bunch wears a mochila [backpack], which makes me suspicious of their authenticity as pilgrims. ... I would like to be enough of a superman to tip their coche de apoyo over the bank of the road and have it tumble into the gully below, forcing them to walk as true 
pilgrims ... I merely pass by silently and unnoticed and move far enough ahead of them to never have to encounter their big mouths and lazy butts again. (188-89; see also 138; 227)

Pilgrim-authors also report how they (or others) can become targets of disdain when they deviate from approved practice. Kerry Egan, for example, suffers the scorn of fellow pilgrims when she chooses on one occasion to stay in the luxury of a hotel rather than a traditional refugio.

There is an unwritten code of the 'proper' way a pilgrim is to walk the Camino ... In this code, the 'real' pilgrims (and that is the term used) are those who start somewhere in France, carry their bags the whole way, never use any form of mechanical transport, stay only in refugios, and lose lots of weight. The less authentic pilgrims are those who have someone helping with the bags, stay in pensiones or hotels, or, worst of all, take cars or trains for part of the journey. (115)

Egan concludes that according to this crude hierarchy 'the real pilgrims are those who suffer for the Camino', and she links this emphasis on suffering to 'ancient ideals of asceticism and penance' (116). It is arguable, however, that the emphasis on suffering as a marker of authenticity has far more contemporary roots in a pilgrim's concern about how their own identity can be authentically constituted in a modern world. For whereas the choice to walk might be critical for the pilgrim pursuing a medieval fantasy, as Nicholas Luard has noted, 'Any sensible medieval pilgrim would always hitch a lift on a passing wagon'. ${ }^{38}$ Medieval pilgrims undoubtedly suffered on the journey to Santiago, but this was largely a necessity born of the belief that the completion of the journey would make the suffering worthwhile. For the modern pilgrim, however, much of the 'suffering' is a matter of choice, embraced in the belief that their pilgrim identity becomes more authentic as they indulge the time-bending spirit of their medieval fantasy.

Numerous Santiago narratives therefore emphasise the degree to which the author has separated from the modern world and engaged with the penitential rigours they associate with the medieval experience. This enables them, as an imaginative narrative strategy at least, to escape modernity and establish a direct link to their idealised pilgrim-type, the medieval pedestrian in search of atonement. When Rudolph proclaims that his experience 'was truly medieval' (33), or Hoinacki that 'I have travelled yet further into the world of the ancient pilgrims' (265), they are announcing the final proof of their authenticity; that they have escaped modernity and established a kinship with those 'real pilgrims' who walked the Camino centuries before. As Kerry Egan notes, 'We [pilgrims] are all connected across time’ (72).

\section{Community}

In the context of developing a universal model for an anthropology of pilgrimage Victor Turner argued that community formation is an intrinsic part of the pilgrim's experience. According to Turner, individuals on pilgrimage enter a 'liminal' space where, free from the structured roles they play in their normal lives, they build spontaneous and egalitarian relationships with fellow pilgrims. ${ }^{39}$ Turner described this impulse as communitas, and argued that the experience is sufficiently powerful that the achievement of communitas is a primary motivation for pilgrimage. The reality of communitas has, however, been rigorously contested in recent pilgrimage 
discourse, with the concept criticised as an idealised representation of the pilgrim experience. ${ }^{40}$ Nonetheless the concept of communitas has remained central to the way in which modern pilgrimage is theorised.

Certainly many pilgrim-authors do narrate the experience of forming temporary but meaningful communities with the fellow travellers they meet on the Camino. Whereas in other contemporary travel narratives an author may relocate from the dysfunctional sociality of western cities in search of a stable, nurturing community, ${ }^{41}$ the Camino has a shifting population with no basis for a permanent community. Nonetheless pilgrim-authors almost universally report sharing a communal bond with the pilgrims they meet in cafes and refugios (Boers 111, 140; Codd 56-7, 126, 178; Egan 18, 198; Kevin 13; Pivonka 77; Selby 158), to the extent that this otherwise normal form of sociality strikes them as being antithetical to the modern world in its generosity and inclusiveness. According to Egan:

A pilgrim experiences communitas, the elimination of differences between people of different ages, classes, and nationalities. Barriers between people are thrown aside as a great feeling of unity and connectedness brings people together in a way that seems impossible within the regular strictures of society. (18)

Kevin Codd relates a similar experience of a pilgrim community that is distinctly at odds with modern expectations:

Now this is an extraordinary thing that I can't imagine happening back home: the instant camaraderie and welcome into the circle that is so much a part of life in this pilgrim world is lost to the fast and fear-laden society that I ordinarily live within. I feel myself less a human being for not having grown up in a world where anyone who walks in the door is presumed to be a friend and is a friend. The loss of this gift is as great as any that our wholesale dive into modernity has caused. (178)

The desire for community also expresses itself in other ways, and often in a manner that allows pilgrim-authors to draw stark contrasts between their medieval fantasy and the reality of modernity. In a number of cases a model form of community is glimpsed in the ancient villages encountered on the Camino, where it forms an important component of an author's nostalgic longing for the medieval past. For Tony Kevin these villages evoke a golden age of community, a period of Spanish history when religious and ethnic differences were supposedly erased.

These villages . . . were designed for 'convivencia' ('living together'). Christians, Jews, and Muslims would have coexisted peacefully in extended families, living in large houses ... . Their occupants would have rubbed shoulders together in the same thriving, easy-going culture of medieval Spain, working, trading, having families, making friends and intermarrying across religions. (113)

Kevin finds evidence of convivencia in both medieval and modern Spain, which he contrasts with the failure of 'our brittle and suspicious Anglophone urban cultures' that have lost 'that vital capacity to relaxedly enjoy one another's company in city streets' (274-75). By way of contrast he lists the various manifestations of modernity that bedevil other western cultures, including 'mindless affluence'; 'cheap, fast-food takeaway meals'; 'bored, neglected children 
sitting alone, playing games at Internet consoles' (275), and the 'daily disappointments of our joyless consumerism' (294). Presiding over these various ills Kevin identifies the global threats of climate change, an unsustainable petro-economy, and a 'market-driven global society' (194).

Lee Hoinacki is another pilgrim-author who constantly reminds his readers of the damage wrought by modernity on previously stable communities. As Hoinacki passes through towns, villages and farms, he finds evidence of the destructive impact of modern technologies and markets. In their wake he finds villages emptied by city based economies, leaving behind the 'vestiges of a community once characterised by a certain wholeness and an inventive economy' (224). In contrast, Hoinacki is given to romanticising the medieval artisans and craftsmen whose skill he finds in evidence in the ancient buildings, walls and bridges that dot the Camino. On several occasions he recounts conversations with the descendants of these craftsmen who continue to eke out a living in the depleted villages.

In his bones, he knows that he does good work, that the way he works gives him a good life, that the product of his work graces the people of his town. But all this is ending. Centuries of solid tradition, sustaining the beauty of these lives in this community, will be smashed, destroyed forever, when his children simply walk away ... A new world has beckoned to his children. They are probably succumbing to its temptations. They do not see that the best they can hope for is to become the adjunct of some machine, made of hardware or software. The more sophisticated the machine, the more they will be absorbed into it, commanded and shaped by it. (93)

The most powerful evocation of community in contemporary Santiago narratives, however, is the frequently expressed bond between the contemporary pilgrim and those who have walked the path before them. As Kerry Egan writes:

This is a field that millions of people have passed before you, this is a fountain that people have drunk from since Roman times. Those ruts in the stone paving were made by thousands of iron wagon wheels trundling along, and in this church people have fallen to their knees and prayed for a thousand years. Someone else was hot and tired and thirsty and overwhelmed before you. (69)

Rita D’Arcy argues that what makes a community of past and present pilgrims is their shared experience and values that are at odds with modernity. According to D'Arcy the modern pilgrim has more in common with the medieval pilgrim than with his or her contemporaries who revel in the doubtful benefits of modernity.

I was caught up in the mystique of the pilgrimages undertaken by millions before me, genuine pilgrims who travelled so far and for so long, to a place which they knew would lift them out of the trials of this life . . . And today, in this world of selfgratification and pamper, I honour the hundreds of believers who are following the same route in the same mode. ${ }^{42}$

In these frequent expressions of community with their forebears we encounter another mechanism by which time for pilgrim-authors is folded, compressed and transcended, as the medieval and modern are imagined as a united moment. As Frey noted, for many contemporary 
pilgrims there is a real immediacy in their association with the medieval pilgrim, to the point where temporal differences are erased.

With the change in linear, directional time, pilgrims often sense that time blends and folds together, past, present, and future coexist. Pilgrims commonly experience themselves with pilgrims of the past as they walk, rest, take shelter, drink at a fountain, cross a bridge, pray in Church. (81-82)

We find this same powerfully imaginative compression of time expressed in Santiago narratives. According to Kevin Codd:

I can almost hear the footfalls of the hundreds of thousands of pilgrims from times gone by shuffling in time with my own footfalls. They are with me. There is a duke to my left, a cobbler to my right ... and a priest wrapped in a threadbare cassock just in front of me. A dry crust of bread is passed from the duke to the cobbler to me to the priest and we each take our bite ... I am grateful to be walking with them across this old stone road. Dirty, bearded, sweaty, suffering far more than I, they are my pals for this moment. (Codd 53; see also 270)

Lee Hoinacki is another who narrates the presence of the medieval pilgrims with him on his journey. Almost from the outset Hoinacki believes that he is being assisted in his travails by the community of past pilgrims.

In the midst of these tortures . . . I think of all those who preceded me, crossing these mountains and then I am struck with the clear and unquestionable realization: they're still here. And they're interested in me . . . They are here to help me, to carry me over the next rise, around the next cliff. (7-8)

For the extent of his journey Hoinacki imagines that he has these medieval forebears as company, contending that, 'In some direct and unambiguous way, I share their experience; I can hope to enter their world (147); and, 'If they had not accompanied me I would never have been able to endure the pain and exhaustion' (272).

This deep association with pilgrims of other eras is one of the essential unifying element of contemporary Santiago narratives, which frequently culminate with the pilgrim-author claiming a place in a trans-millennial community of pilgrims. Almis Simankevicius declares that, 'I now felt I had taken my place beside all the millions of pilgrims who had come before me. I felt part of the legend of Santiago de Compostela' (131); and Kevin Codd that, 'I am not only a lone pilgrim out here; I am one part of a grand pilgrimage extending beyond the horizon and back into time’ (176). These modern pilgrims have achieved a sense of a fulfilled purpose, partially born from having completed the journey to Santiago, but even more so from having imaginatively connected to the spirit of medieval pilgrimage. In doing so they claim to have escaped that which is mundane, alienating and transitory in the globalised cultures of modernity, and joined their lives to a shared human enterprise that spans both time and space.

\section{Conclusion}


It is easy to be sceptical about Santiago narratives and their romanticisation of the medieval pilgrim. After all, contemporary pilgrimage literature has emerged as a genre with its own conventions and clichés, and inevitably aspects of the literary journey will be crafted by an author's need to reflect a sense of their subjective experience while adhering to readers' expectations. Two of the key conventions of contemporary pilgrim writing are that the journey should be represented as an experience that is not available in the pilgrim's 'normal' life, and that a successful pilgrimage is seen as being in some way transformative, and even life-changing. In the context of Santiago narratives both of these conventions can be addressed by strategies that foreground the medieval aspects of the experience and thereby create the author's subjectivity as being outside of, and in opposition to, modernity and its associated values. Pilgrim-author Jack Hitt has warned of 'literary devices signifying the expectations of the genre [rather] than the truth of what happened' (253), and the abundantly used trope of medievalism might be seen as just such a device. In a time where even the remotest parts of the Camino are within reach of mobile phones, credit cards and public transport, and pilgrims can avail themselves of the benefits of modern comforts in the form of lightweight and weatherproof clothing and shoes, the claim to have undergone a medieval experience can seem spurious and affected.

What can be said confidently of recent Santiago narratives, however, - with their romantic longing for a golden age of pilgrimage, expressed as a desire to embrace an authentic past and an ersatz community by imaginatively crossing time - is that they are absolutely of their own time. Contemporary pilgrim writing frequently produces a form of hyper-travel narrative, whereby elements that are common in other modern travel writing (the nostalgic attraction to a preindustrial and prematerialist world coupled with a distrust of modernity) are deepened and intensified. In their exaggerated concern with authenticity and community, these texts collectively provide a critique of both non-pilgrim tourism and the failed sociality offered by modernity. In this way, and in common with the best travel writing, Santiago narratives offer a profound reflection, not only on the land, places and people encountered in the course of a journey, but on the process of modern travel, and on the time and place to which the traveller returns.

1 Paulo Coelho, The Pilgrimage: A Contemporary Quest for Ancient Wisdom (New York: Harper, 1998), 232.

2 Heather Henderson, 'The Travel Writer and the Text: "My Giant Goes with Me Wherever I Go"', in Temperamental Journeys: Essays on the Modern Literature of Travel, Michael Kowalewski ed., (Athens: University of Georgia Press, 1992), 230-248 (233). James Harpur, Sacred Tracks: 2000 Years of Christian Pilgrimage (London: Francis Lincoln, 2002), 99.

4 Nancy Louise Frey, Pilgrim Stories: On and Off the Road to Santiago, (Berkeley: University of California Press, 1998). Further page citations given parenthetically in the text.

5 Iglesia Compostelana, 'Distribucion de los Peregrinos', La Perigrinacion a Santiago. 12 Aug. 2008. Accessed 14 August 2010, < http://www.archicompostela.org/Peregrinos/Estadisticas/peregestageneral.htm> The concept of the Holy Year was introduced by the Catholic Church in the twelfth century, and offers pilgrims the opportunity to be granted additional remissions on their sins. That 
pilgrim numbers rise in Holy Years is evidence that religious motives for undertaking the pilgrimage remain strong. 2010 is again a Holy Year.

See for example; Theresa Burkhardt-Felder, Pray for Me in Santiago: Walking the Ancient Pilgrim Road to Santiago de Compostela, (Fremantle: Fremantle Arts Centre Press, 2005), 271; Lee Hoinacki, El Camino: Walking to Santiago de Compostela, (University Park: Pennsylvania State University Press, 1996); Tony Kevin, Walking the Camino: A Modern Pilgrimage to Santiago, (Melbourne: Scribe, 2007), 172. Further page citations given parenthetically in the text.

7 Nicholas T. Parsons, Worth the Detour: A History of the Guidebook, (Phoenix Mill: Sutton, 2007), 77. Further page citations given parenthetically in the text.

8 There are a number of contemporary translations of the Codex Calixtinus available. One of the most comprehensive is; The Pilgrim's Guide: A Critical Edition, 2 vols, (London: Harvey Miller, 1998).

9 Maryjane Dunn and Kay Davidson, 'Bibliography of the Pilgrimage: The State of the Art', The Pilgrimage to Compostela in the Middle Ages: A Book of Essays, Maryjane Dunn and Kay Davidson, eds., (New York: Garland, 1996), xxiii-xlviii.

10 The estimation of 120 personal accounts in English is based on an examination of library catalogues and bibliographies, in particular WorldCat, the largest union catalogue of international library holdings. Inconsistent subject cataloguing makes an exact calculation difficult. WorldCat indicates that English language accounts are dominant, but numerous other languages (both European and Asian) are represented. Some Santiago narratives are underdeveloped and non-reflexive, being lightly edited versions of diaries apparently kept while on the Camino. The texts featured in this paper have been selected because they offer more reflective accounts of the experience of pilgrimage in the modern world.

11 Donald R. Howard, Writers and Pilgrims: Medieval Pilgrimage Narratives and Their Posterity, (Berkeley: University of California Press), ix.

12 Simon Coleman and John Elsner, Pilgrim Voices: Narrative and Authorship in Christian Pilgrimage, (New York: Berghahn, 2002), 5.

13 Patrick Holland and Graham Huggan, Tourists with Typewriters: Critical Reflections on Contemporary Travel Writing, (Ann Arbor: The University of Michigan Press, 1998).

14 Walter Starkie, The Road to Santiago: Pilgrims of St James. London: John Murray, 2003 [1957], 138. Further page citations given parenthetically in the text.

15 See for example; Jane Christmas, What the Psychic Told the Pilgrim, (Adelaide: East Street, 2007), 170; Kerry Egan, Fumbling: A Journey of Love, Adventure, and Renewal on the Camino de Santiago, (New York: Broadway, 2006), 69; Edwin Mullins, The Pilgrimage to Santiago, [1974] (Newton Abbott: Readers Union, 1975), 39-46; Conrad Rudolph, Pilgrimage to the End of the World: The Road to Santiago de Compostela, (Chicago: The University of Chicago Press, 2004), 5; Susie Tarver, Field of Stars: A Story of the Road to Santiago, (Lancashire: Schiel \& Denver, 2009), 44; Mary E. Wilkie, Walking to Santiago: Diary of a Pilgrimage, (Armidale: Cranleigh House, 2001), 12. Further page citations to these sources will be given parenthetically in the text.

16 Shirley MacLaine, The Camino: A Journey of the Spirit, (New York: Pocket Books, 2000).

17 Hape Kerkeling, Ich Bin Dann Mal Weg: Meine Reise Auf Dem Jakobsweg, (München: Malik, 2006). Translated as; I'm Off Then: Losing and Finding Myself on the Camino de Santiago, (New York: Free Press, 2009). 
${ }^{18}$ Ben Nimmo, Pilgrim Snail: Busking to Santiago, (London: Flamingo, 2001). Further page citations given parenthetically in the text.

19 Tim Moore, Spanish Steps: Travels with My Donkey, (London: Jonathan Cape, 2004).

20 Diana Webb, Medieval European Pilgrimage (Houndmills: Palgrave, 2002).

${ }^{21}$ Alison Russell, Crossing Boundaries: Postmodern Travel Literature, (Houndmills: Palgrave, 2000), 4.

${ }^{22}$ Elyn Aviva, Following the Milky Way: A Pilgrimage on the Camino de Santiago, $2^{\text {nd }}$ ed, (Boulder: Pilgrims Progess, 2001), xxxiii. Further page citations given parenthetically in the text.

${ }^{23}$ See also; Rene Freund, On Foot to the End of the World, (London: Haus, 2006), 182; Kevin, Walking the Camino, 172; Rudolph, Pilgrimage, 38; Rupp, Walk in a Relaxed Manner, 27.

${ }^{24}$ Jack Hitt, Off the Road: A Modern-Day Walk Down the Pilgrim's Route into Spain, (New York: Simon and Schuster, 2005), 250-1. Further page citations given parenthetically in the text.

${ }^{25}$ Dave Pivonka, Hiking the Camino: Five Hundred Miles with Jesus, (Cincinnati: Servant, 2009), 11. Further page citations given parenthetically in the text.

${ }^{26}$ Bettina Selby, Pilgrim's Road: A Journey to Santiago de Compostela, ([no place]: Mountain House Publishing, 1994).

${ }^{27}$ Almis Simankevicius, Santiago: Walking the Pilgrim Path: A Journey through Spain from Pamplona to Santiago de Compostela, (North Sydney: Good Walking Books, 1999), 34. Further page citations given parenthetically in the text.

${ }^{28}$ Joyce Rupp, Walk in a Relaxed Manner: Life Lessons from the Camino, (Maryknoll: Orbis, 2005), 81.

${ }^{29}$ Susan Alcorn, Camino Chronicle: Walking to Santiago, (Oakland: Shepherd Canyon, 2006), 117.

30 Arthur Paul Boers, The Way is Made by Walking: A Pilgrimage Along the Camino de Santiago, (Downers Grove: Intervarsity Press, 2007), 161. Further page citations given parenthetically in the text.

${ }^{31}$ Elizabeth Best and Colin Bowles, The Year We Seized the Day: A True Story of Friendship, Fury and Sore Feet, (Crows Nest: Arena, 2007), 295. Further page citations given parenthetically in the text.

32 Kathryn Harrison, The Road to Santiago, (Washington: National Geographic, 2003): 101. Further page citations given parenthetically in the text.

${ }^{33}$ Kevin A. Codd, To the Field of Stars: A Pilgrim's Journey to Santiago de Compostela, (Grand Rapids: William B. Eerdmans, 2008), 106. Further page citations given parenthetically in the text.

34 As Dean MacCannell has argued, however, in his discussion of 'staged tourism', many tourists share the desire for authentic experience. Dean MacCannell, The Tourist: A New Theory of the Leisure Class, (London: Macmillan, 1976): 91-107. The extent to which the concept of authenticity has been adopted by the tourism industry is apparent in; Ian Yeoman, Danna Brass and Una McMahon Beattie, 'Current Issue in Tourism: The Authentic Tourist,' Tourism Management 28 (2007): 1128-38.

${ }^{35}$ See; Ellen Badone and Sharon R. Roseman, 'Approaches to the Anthropology of Pilgrimage and Tourism', in Intersecting Journeys: The Anthropology of Pilgrimage and Tourism, E. Badone and S. Roseman, eds., (Champaign: University of Illinois Press, 2004): 1-23; Erik 
Cohen, 'Pilgrimage and Tourism: Convergence and Divergence', in Sacred Journeys: The Anthropology of Pilgrimage, Alan Morinis, ed., (Westport: Greenwood, 1992): 47-61; N. H. H. Graburn, 'Tourism: The Sacred Journey', in Hosts and Guests: The Anthropology of Tourism. V. Smith, ed., (Oxford: Blackwell, 1978): 33-47; Bryan Pfaffenberger, 'Serious Pilgrims and Frivolous Tourists: The Chimera of Tourism in the Pilgrimages of Sri Lanka,' Annals of Tourism Research 10 (1983): 57-74; Ian Reader and Tony Walter, Pilgrimage in Popular Culture, (Houndmills: Macmillan, 1993).

36 Victor Turner and Edith Turner, Image and Pilgrimage in Christian Culture, (Oxford: Blackwell, 1978), 20. Further page citations given parenthetically in the text.

${ }^{37}$ The test of authenticity can be stern, with Kevin Codd describing as a 'real pilgrim', one who 'has actually put on her boots, hefted her mochila onto her back, and stepped out the front door of her own home to walk all the way to Santiago' (44; see also 142; and O’Regan, 13).

38 Nicholas Luard, The Field of the Star: A Pilgrim's Journey to Santiago de Compostela, (London: Michael Joseph, 1998): 183.

39 Victor Turner, The Ritual Process: Structure and Anti-structure, (Ithica: Cornell University Press, 1969). See also Turner and Turner (1974, 243-55).

40 For example: Simon Coleman, 'Do You Believe in Pilgrimage? Communitas, Contestation and Beyond,' Anthropological Theory 2 (2002): 355-68; John Eade and Michael Sallnow, 'Introduction', in Contesting the Sacred: The Anthropology of Christian Pilgrimage, $2^{\text {nd }}$ ed, J. Eade and M. Sallnow, eds. (Urbana: University of Illinois Press, 2000): 1-29; Darlene M. Juschka, 'Whose Turn is it to Cook? Communitas and Pilgrimage Questioned', Mosaic 36 (2003): 189-204.

41 Paul Genoni, 'Unbecoming Australians: Crisis and Community in the Australian Villa/ge Book', Australian Literary Studies 23, no. 2 (2007): 213-229.

42 Rita M. Darcy, Cruising the Camino by a Would be Pilgrim: The Way to Santiago de Compostela, (Mansfield: Warrior, 1997), 65.

http://peregrinossantiago.es/eng/post-peregrinacion/estadisticas/ 